Ю. В. Бохан, Ф. О. Чмиленко

Кіровоградський державний педагогічний університет

Дніпропетровський національний університет

\title{
ТЕСТ-МЕТОДИ ХІМІЧНОГО АНАЛІЗУ 3 ВІЗУАЛЬНОЮ ТА СКАНЕРНОЮ ІНДИКАЦІЮ В ЕКОАНАЛІТИЧНОМУ МОНІТОРИНГУ ПРИРОДНИХ ВОДОЙМ КІРОВОГРАДЩИНИ
}

Розглянуто особливості тестового аналізу з візуальною та сканерною індикацісю для виявлення та напівкількісного визначення загальних забруднювачів і показників якості водних об'єктів. Запропоновано оцінювання деяких метрологічних характеристик відомих тестових методик визначення $p H$, концентрації розчиненого кисню, нітрат- та фосфат-іонів, іонів заліза із застосуванням візуальних та комп'ютерних сканер-технологій.

\author{
Y. V. Bokhan, F. O. Chmilenko \\ Kirovograd State Pedagogical University \\ Dnipropetrovsk National University
}

\section{TEST-METHODS OF CHEMICAL ANALYSIS WITH VISUAL AND SCANNER INDICATION IN ECOANALYTICAL MONITORING OF NATURE RESERVOIRS OF KIROVOGRAD REGION}

The features of test analysis with visual and scanner indication for the exposure and semiquantitative determination of general pollutants and indices of water bodies' quality are considered. Evaluation of some metrological descriptions of the known test-methods of $p H$ determination, concentrations of the dissolved oxygen, nitrate- and phosphate-ions, ions of iron with visual and computer scanner-technologies using is offered.

\section{Ветуп}

Хімічний аналіз об’єктів навколишнього середовища - важливе джерело інформації для оцінки стану навколишнього середовища, прогнозування екологічних ситуацій та прийняття природоохоронних рішень. Ефективність аналітичного контролю залежить від системи його організації, забезпечення якості результатів хімічного аналізу за рахунок приладного, реактивного забезпечення тощо [6]. Використання простих, експресних і дешевих методів аналізу, що не ускладнюють аналітичний процес наявністю спеціальних лабораторних умов і персоналу спеціальної кваліфікації, якими і є тест-методи, сприяє ефективному впровадженню відомих методик тестового аналізу для контролю хімічного складу об'єктів довкілля, зокрема таких, як узагальнені показники якості вод: $p H$, концентрація розчиненого кисню, вміст нітрат-іонів тощо. За принципом дії тестметоди умовно можна поділити на хімічні (у тому числі біохімічні) та біологічні [1]. Основа хімічних тест-методів - аналітичні реакції та реагенти, що дозволяють візуально чи за допомогою портативного приладу спостерігати аналітичний ефект. Для виявлення та визначення речовин у хімічних тест-методах використовують реагенти різної природи (органічні та неорганічні) та різного механізму дії (кислотно-основні, комплексотвірні, 
окисно-відновні і ті, що беруть участь у синтезі нових хромогенних сполук). Використовують реакції, кращі за чутливістю, вибірковостю і стійкі при збереженні реагенти. Це найбільше вивчені реагенти (наприклад, ті, що використовуються у краплинному аналізі неорганічних і органічних сполук) [4; 8]. Синтезують і нові, чутливіші та вибіркові реагенти [5; 7; 9], модифікують відомі [2; 3]. Актуальними залишаються пошук нових способів іммобілізації та модифікації аналітичних реагентів, розробка на їх основі нових тест-систем з удосконаленими способами реєстрації аналітичного сигналу та напівкількісного визначення аналізованих речовин. Із поширенням цифрового фотографування, сканування та комп'ютерних технологій зображення з'явився об'єктивніший, швидший i більше автоматизований спосіб оцінки кольорових характеристик забарвлених зразків. Методика заснована на скануванні забарвлених кольорових шкал за допомогою сканера та аналізі одержаного файла зображення за характеристиками кольоровості або відображальною здатністю чи яскравістю. Мета роботи полягає в обгрунтуванні можливості сканерної індикації до тест-систем та оцінюванні метрологічних характеристик методик із різними способами індикації (візуальним і сканерним).

\section{Матеріал і методи досліджень}

Використовували реактиви таблетованої форми, виготовлені фірмою LaMotte (Честертон, штат Меріленд, США); секундомір, папір універсальний індикаторний; реактиви не нижче, ніж ч. д. а. Визначали наступні параметри природної води: $p H$, твердість, концентрація розчиненого кисню та його біохімічна потреба, а також концентрації іонів $\mathrm{Cu}^{2+}, \mathrm{Fe}^{2+}, \mathrm{Fe}^{3+}, \mathrm{NO}_{3}^{-}$і $\mathrm{PO}_{4}^{3-}$. В аналізі визначали лише чотири параметри: $\mathrm{pH}$ та концентрації розчиненого $\mathrm{O}_{2}, \mathrm{NO}_{3}^{-}$і $\mathrm{PO}_{4}^{3-}$. Таблетки виготовлені у формі циліндра діаметром 6 мм і висотою 2 мм. Об'єм кожної таблетки - 56,55 мм ${ }^{3}$, загальна площа поверхні - 94,25 мм². Усі таблетки добре розчиняються у воді при будь-якій температурі. Загальні характеристики використаних тест-систем наведені у таблиці 1.

Кольорові шкали зразків порівняння підібрані відповідно до ряду величин концентрації компонента, що збільшуються в геометричній прогресії. Кольорові шкали, за допомогою яких визначалось значення того чи іншого параметра, виготовлені фірмою LaMotte у вигляді табличок із цупкого паперу, ламінованих з обох боків. Розміри табличок - (79-84) х (118-121) мм, товщина - 0,4 мм. На одному боці таблички на білому фоні безпосередньо нанесена колірна шкала, проградуйована (за винятком $p H)$ у одиницях $p p m$. При визначенні феруму використовували власну кольорову шкалу, виготовлену за допомогою комп'ютерних сканер-технологій.

Прочедури тестування. Для аналізу використані пробірки, що герметично закривалися: пластикові (ємністю 10 мл) 3 капроновими пробками (визначення $\mathrm{pH},\left[\mathrm{NO}_{3}{ }^{-}\right] \mathrm{ra}\left[\mathrm{PO}_{4}{ }^{3-}\right]$ ) та скляна (ємністю 4,8 мл) з пластмасовою пробкою, що вгвинчується (визначення $\left.\left[\mathrm{O}_{2}\right]\right)$. Контакт таблетованих реагентів зі стандартними розчинами проводять за допомогою наступних процедур: заповнюють тестову пробірку (0106) водою до позначки 10 мл та додають одну таблетку $p H$ Wide Range TestTab® (6459) й закривають пробірку пробкою та струшують доти, доки таблетка не розчиниться. Після цього візуально зіставляють забарвлення реакційної зони зразка 3 кольоровою і, відповідно, концентраційною шкалами. Процедури тестування дають можливість вимірювати за однією і тією ж кольоровою шкалою в різних діапазонах концентрацій варіюванням об’єму аналізованої проби води.

Методики експресного напівкількісного тестового визначення неорганічних іонів за допомогою набору таблетованих індикаторних засобів установлюють порядок і процедуру напівкількісного визначення кожного компонента. У процесі підготовки до аналізу створюють необхідні умови збереження аналітичної форми компонента, що визнача- 
ється, і $p H$ середовища. При зіткненні таблетованого індикаторного засобу з аналізованим розчином і витримці на повітрі за інтенсивністю забарвлення реакційної зони оцінюють візуально (зіставляють інтенсивність реакційного забарвлення в індикаторній пробірці з відповідними зразками порівняння кольорової шкали; визначення проводять тричі) або сканерною індикацією (попередньо сканують забарвленні кольорові шкали та обробляють цифрові зображення у графічному редакторі Adobe Photoshop, будують градуйовані залежності у координатах інтенсивність забарвлення - концентрація, проводячи далі за ними сканерну індикацію: забарвлені пластинки носіїв розміщують у сканері та сканують у кольоровому режимі RGB 24 біт із 300 ppi; при використанні тестових пробірок за допомогою цифрової фотокамери знімають забарвлення реакційної зони та обробляють одержані фотографічні цифрові зображення у графічному редакторі Adobe Photoshop) вміст іона у воді. Основні метрологічні дані, що містяться в методиках, наведені у таблиці 2. Методики призначені для визначення мікрокількостей неорганічних іонів у таких об'єктах як питні води, стоки, води водойм, технологічні розчини, грунтові витяжки з урахуванням специфіки підготовки й обробки проб цих об'єктів. Аналіз проводять у лабораторних і польових умовах. Приклад повного викладу методики виконання вимірів (MBB) як зразка запропонованих методик експресного тестового напівкількісного визначення іонів наведений далі.

Таблиия 1

Загальна характеристика тест-систем, застосованих у ході аналізу

\begin{tabular}{|c|c|c|c|c|c|c|}
\hline Аналіт & $\begin{array}{c}\text { Тип } \\
\text { таблетки }\end{array}$ & $\begin{array}{l}\text { Реагент, } \\
\text { індикаторна } \\
\text { система }\end{array}$ & Носій & \begin{tabular}{|c|} 
Спосіб \\
визначення \\
концен- \\
трації \\
\end{tabular} & $\begin{array}{c}\text { Зміна } \\
\text { забарвлення } \\
\text { носія }\end{array}$ & $\begin{array}{l}\text { Діапазон, що } \\
\text { визначається }\end{array}$ \\
\hline$p H$ & $\begin{array}{c}\text { pH Wide Range } \\
\text { TestTabs }{ }^{\circledR} \\
(6459)\end{array}$ & $\begin{array}{c}\text { змішаний } p H \text { індикатор } \\
\text { (бромтимоловий синій, } \\
\text { метиловий жовтогаря- } \\
\text { чий, фенолфталеїн, } \\
\text { алізариновий червоний) }\end{array}$ & папір & A, B & $\begin{array}{c}\text { від жовто- } \\
\text { гарячого до } \\
\text { бузкового }\end{array}$ & $p H 1-14$ \\
\hline $\begin{array}{l}\text { Розчи- } \\
\text { нений } \\
\text { кисень } \\
\end{array}$ & \begin{tabular}{|c} 
dissolved oxygen \\
TestTabs® \\
$(3976)$ \\
\end{tabular} & $\begin{array}{l}\text { натрій цитрат, } \\
\text { 2,4-діамінофенол- } \\
\text { дигідрохлорид }\end{array}$ & папір & $\mathrm{A}, \mathrm{B}$ & $\begin{array}{c}\text { від безбарвного } \\
\text { до яскраво- } \\
\text { жовтогарячого } \\
\end{array}$ & $2-15$ мг/л \\
\hline $\mathrm{NO}_{3}^{-}$ & $\begin{array}{c}\text { nitrate № } 1 \\
\text { TestTabs }{ }^{\circledR} \\
(2799) \\
\end{array}$ & $\begin{array}{c}\text { сульфанілова та } \\
\text { хромотропова } \\
\text { кислота, цинк } \\
\end{array}$ & папір & A, B & $\begin{array}{c}\text { від безбарвного } \\
\text { до яскраво- } \\
\text { жовтогарячого } \\
\end{array}$ & 0,5-2000 мг/л \\
\hline $\mathrm{PO}_{4}^{3-}$ & $\begin{array}{c}\text { Phosphorus } \\
\text { TestTabs }{ }^{\circledR} \\
(5422) \\
\end{array}$ & $\begin{array}{c}\text { амоній молібдат, ас- } \\
\text { корбінова кислота }\end{array}$ & папір & A, B & $\begin{array}{c}\text { від безбарвного } \\
\text { до насичено- } \\
\text { синього } \\
\end{array}$ & 1-500 мг/л \\
\hline $\mathrm{Fe}^{3+}$ & - & $\begin{array}{l}\text { тіоціанат амонію } \\
\text { або калію }\end{array}$ & $\begin{array}{c}\text { папір або } \\
\text { хромато- } \\
\text { графічна } \\
\text { пластинка } \\
\end{array}$ & Б, В & $\begin{array}{c}\text { від жовтого до } \\
\text { червоно- } \\
\text { бурштинового }\end{array}$ & 0,1-1 мг/л \\
\hline
\end{tabular}

Примітки: *А - візуальна оцінка інтенсивності забарвлення розчину після внесення у нього індикаторних таблеток зі стандартною кольоровою шкалою; Б - візуальна оцінка інтенсивності забарвлення тест-форми після пропускання через неї певного об'єму розчину; В - оцінка інтенсивності забарвлення тест-форми після пропускання через неї певного об’єму розчину за допомогою сканер-технологій.

Обробка результатів аналізу. Порядок визначення залежить від відповідності забарвлення колірної плями індикаторної смуги забарвленню конкретних зразків. Якщо інтенсивність забарвлення обох плям ледве слабкіша чи сильніша інтенсивності забарвлення конкретного зразка стандартної колірної шкали, за остаточний результат аналізу приймають це значення концентрації. Якщо інтенсивності забарвлення отриманих плям 
близькі між собою і до проміжного для двох суміжних зразків стандартної колірної шкали, то за остаточний результат аналізу приймають середнє значення між цими концентраціями. Якщо одна з двох отриманих плям перевищує за своєю інтенсивністю найближчий зі зразків порівняння стандартної колірної шкали, а друга забарвлена менш інтенсивно, ніж суміжний зразок порівняння для нижчої концентрації, то результати рівнобіжних визначень вважають недостовірними й аналіз повторюють. При повторному відтворенні таких самих результатів методику визнають непридатною для контролю води за даним забруднювачем.

Методика експресного тестового напівкількісного визначення іонів феруму у воді. Методика призначена для експресного тестового напівкількісного визначення іонів феруму у питній воді, стоках, водоймах у лабораторних і польових умовах. Відбір проб виконують за ДСТ 24481-80. Пробу відбирають у день аналізу. Допускається збереження при кімнатній температурі не більше 72 годин. При необхідності тривалішого збереження пробу консервують додаванням 3 мл концентрованої хлоридної кислоти. Запропонована методика базується на сорбції іонів $\mathrm{Fe}^{3+}{ }_{3} 0,1 \mathrm{M}$ нітратних розчинів на хроматографічному папері та подальшому виявленні цих іонів $10 \%$ розчином калій тіоціанату або амоній тіоціанату. У стакан ємністю 50 мл вносять 10 мл аналізованого розчину, створюють кислотність $0,1 \mathrm{M}$ за нітратною кислотою введенням 0,2 мл $5 \mathrm{M} \mathrm{HNO}$ (5 крапель), вносять пластинку носія та помішують розчин протягом 5-7 хвилин. Розчин зливають на пластинку, додають 3-5 крапель $10 \%$ розчину $K S C N$ (або $N H_{4} S C N$ ). Напівкількісну оцінку інтенсивності зміни забарвлення залежно від концентрації феруму роблять за допомогою кольорової шкали, використовуючи як метод індикації візуальний спосіб або сканер-технології. Кольорову шкалу готують аналогічним чином, вводячи замість 10 мл аналізованого розчину по 10 мл дистильованої води і 1,5, 3,0, 6,0, 12,0 мкг феруму (III), що відповідає концентраціям 0,15, 0,30, 0,60 та 1,20 мг/л. Кольорова шкала нестійка, тому ії готують одночасно 3 аналізом проби або використовують імітацію шкали. Виготовлення кольорової шкали та сам аналіз набагато спрощується при використанні комп'ютерних сканер-технологій. Межа виявлення $\mathrm{Fe}^{3+}$ дорівнює 0,15 мг/л. Тривалість визначення - 10 хвилин без урахування перевірки колірної шкали за градуювальними розчинами.

\section{Результати та їх обговорення}

Експрес-тести служать у першу чергу для попередньої оцінки вмісту компонентів у водних об'єктах. Хімічні тест-методи з візуальним спостереженням можуть забезпечити якісне чи напівкількісне визначення компонента (табл. 2).

Метод прийнятний, якщо супроводжується колірним ефектом, що чітко спостерігається візуально і легко індикується та вимірюється. Напівкількісну оцінку інтенсивності зміни забарвлення реакційної зони залежно від концентрації компонента, що визначається, за запропонованими методиками роблять візуально або 3 використанням сканертехнологій, використовуючи стандартну колірну шкалу зразків порівняння, що відтворює натуральну колірну шкалу. Натуральну шкалу одержують у вигляді забарвлених реакційних плям паперу, що утворюються при роботі з градуювальними розчинами. Стандартну колірну шкалу виготовляють залежно від світлоти, контрастності та насиченості вихідного та кінцевого колірних зразків, потім, відповідно до колірної шкали зразків порівняння, підбирають концентрації. У такий спосіб створюють імітацію колірної шкали. Тест-системи апробовані при аналізі модельних водних розчинів і зразків природних вод із використанням колірних шкал. Метрологічні характеристики використаних методик задовольняють вимоги, що висуваються до тест-методів аналізу та незначно поліпшуються у випадку застосування сканер-технологій для індикації та визначення кінцевої концентрації аналітів. 
Результати тест-аналізу аналітів у природних водах річок міста Кіровоград (Інгул, Сугоклія, Біянка) із візуальною та сканерною індикацією $\left(X \pm \Delta X / S_{r}, n=3, p=0,05\right)$

\begin{tabular}{|c|c|c|c|}
\hline Аналіт & $\begin{array}{c}\text { Об'єкт аналізу, } \\
\text { номер проби }\end{array}$ & $\begin{array}{c}\text { Візуальна індикація, } \\
\text { мг/л }\end{array}$ & \begin{tabular}{|c|}
$\begin{array}{c}\text { Індикація за допомогою комп'ютерних } \\
\text { сканер-технологій, мг/л }\end{array}$ \\
\end{tabular} \\
\hline \multirow{3}{*}{$p H$} & 1 & $7,0 \pm 0,50 / 0,34$ & $7,9 \pm 0,43 / 0,29$ \\
\hline & 2 & $8,0 \pm 0,50 / 0,35$ & $8,5 \pm 0,35 / 0,24$ \\
\hline & 3 & $9,0 \pm 0,46 / 0,44$ & $8,4 \pm 0,36 / 0,35$ \\
\hline \multirow{3}{*}{$\begin{array}{c}\mathrm{O}_{2} \\
\text { (розчинений) }\end{array}$} & 1 & $14,39 \pm 0,27 / 0,26$ & $13,34 \pm 0,15 / 0,22$ \\
\hline & 2 & $14,65 \pm 0,33 / 0,47$ & $15,95 \pm 0,23 / 0,32$ \\
\hline & 3 & $13,50 \pm 0,61 / 0,55$ & $13,22 \pm 0,33 / 0,24$ \\
\hline \multirow{3}{*}{$\mathrm{NO}_{3}^{-}$} & 1 & $4,50 \pm 0,45 / 0,66$ & $4,24 \pm 0,33 / 0,36$ \\
\hline & 2 & $5,22 \pm 0,44 / 0,34$ & $5,22 \pm 0,21 / 0,24$ \\
\hline & 3 & $2,21 \pm 0,28 / 0,53$ & $2,56 \pm 0,22 / 0,31$ \\
\hline \multirow{3}{*}{$\mathrm{PO}_{4}^{3-}$} & 1 & $28,61 \pm 0,25 / 0,45$ & $28,29 \pm 0,23 / 0,32$ \\
\hline & 2 & $29,19 \pm 0,47 / 0,43$ & $29,19 \pm 0,55 / 0,21$ \\
\hline & 3 & $29,21 \pm 0,48 / 0,43$ & $29,25 \pm 0,33 / 0,33$ \\
\hline \multirow{3}{*}{$\mathrm{Fe}^{3+}$} & 1 & $0,97 \pm 0,21 / 0,55$ & $0,97 \pm 0,11 / 0,25$ \\
\hline & 2 & $0,38 \pm 0,39 / 0,39$ & $0,38 \pm 0,19 / 0,34$ \\
\hline & - & $0,58 \pm 0,14 / 0,40$ & $0,58 \pm 0,14 / 0,27$ \\
\hline
\end{tabular}

\section{Висновки}

Межа виявлення визначених компонентів практично не залежить від способу індикації i, скоріше за все, визначається типом хімічної реакції. Перевага сканертехнологій порівняно з візуальною індикацією - висока відтворюваність (про що свідчить зниження стандартних відхилень), збільшення швидкості отримання результатів.

\section{Бібліографічні посилання}

1. Амелин В. Г. Тест-метод с использованием индикаторных бумаг для определения тяжелых металлов в сточных и природных водах // Журн. аналит. химии. - 1999. - Т. 54, № 6. - С. 651-658.

2. Амелин В. Г. Применение в тест-методах индикаторных бумаг, содержащих дитизонаты металлов // Журн. аналит. химии. - 1999. - Т. 54, № 7. - С. 753-757.

3. Амелин В. Г. Применение в тест-методах индикаторных бумаг, содержащих малорастворимые комплексы металлов с диэтилдитиокарбаминататом // Журн. аналит. химии. - 1999. T. 54, № 10. - С. 1088-1093.

4. Блистерные капельно-таблетные тесты на нитраты и нитриты / Д. А. Князев, В. М. Иванов, Ю. А. Золотов и др. // Журн. аналит. химии. - 2002. - Т. 57, № 1. - С. 85-92.

5. Великородный А. А. Тест-определение анилина в растворах на основе реакции азосочетания с аналитическими реагентами, включенными в ксерогели кремниевой кислоты / А. А. Великородный, Е. И. Моросанова, Ю. А. Золотов // Журн. аналит. химии. - 2000. - Т. 55, № 10. - С. 1105-1110.

6. Кузьмин Н. М. Экоаналитический мониторинг // Журн. аналит. химии. - 1999. - Т. 54, № 9. C. 902-908.

7. Моросанова Е. И. Индикаторные порошки на основе модифицированных ксерогелей для твердофазно-спектрофотометрического и тест-определения аскорбиновой кислоты и гидразинов / Е. И. Моросанова, Е. А. Резникова, А. А. Великородный // Журн. аналит. химии. - 2001. - Т. 56, № 2. - С. 195-200.

8. Островская В. М. Экспрессное тест-определение пероксида водорода реагентными индикаторными полосами / В. М. Островская, Ю. А. Золотов, А. В. Давыдов // Журн. аналит. химии. 1999. - Т. 54, № 8. - С. 860-868.

9. Тест-методы для визуального спектрофотометричного и хроматографического определения аминосоединений в воздушных и водных середах / М. И. Евгеньев, С. Ю. Гармонов, И. И. Евгеньева и др. // Журн. аналит. химии. - 1998. - Т. 53, № 2. - С. 175-186.

Надійшла до редколегії 03.03.2007 